\title{
Biological parameters of two syrphid fly species Ischiodon scutellaris (Fabricius) and Episyrphus balteatus (DeGeer) and their predatory potential on wheat aphid Schizaphis graminum (Rondani) at different temperatures
}

\author{
Muhammad Faheem ${ }^{1,2^{*}}$, Shafqat Saeed ${ }^{3}$, Asif Sajjad ${ }^{4}$, Muhammad Razaq ${ }^{5}$ and Faheem Ahmad $^{6^{*}}$ (D)
}

\begin{abstract}
Syrphid flies, Ischiodon scutellaris (Fabricius) and Episyrphus balteatus (DeGeer), are among the most common aphidophagous species in wheat growing areas of Punjab, Pakistan. Exploit predatory species efficiently in any biological control program requires an in-depth understanding of predator and prey interactions. The present study was conducted aiming to explore and compare the predatory potential of these predatory species against the wheat aphid, Schizaphis graminum (Rondani) along with their relative fitness at different temperatures in terms of duration of lifecycle stages under laboratory conditions. The shortest egg and pupal durations were observed at $33{ }^{\circ} \mathrm{C}$, followed by 27 and $23^{\circ} \mathrm{C}$. Females of both species had longer life span (20.4 and 22.4 days) compared to the respective males (17.2 and 16.2 days). The pupal stage for I. scutellaris was significantly shorter than for E. balteatus at different temperatures; but statistically insignificant differences were found for any other life stage. The larvae of I. scutellaris consumed significantly more aphids (438.16) than E. balteatus (398.37) during their larval life span, and this difference was significant during the 1st and 3rd instars. However, the average daily prey intake of both species was found similar until the 10th day after hatching, and thereafter, I. scutellaris consumed significantly higher numbers of aphids/day. Obtained results may offer a baseline data for future conservation studies on biological control of aphids.
\end{abstract}

Keywords: Hover flies, Ischiodon scutellaris, Episyrphus balteatus, Predatory potential, Developmental periods, Schizaphis graminum

\section{Background}

The wheat aphid (Schizaphis graminum Rond.) causes significant annual losses to world wheat production (Belay and Araya, 2015). It damages wheat crop directly through feeding on phloem tissues as well as indirectly by serving as primary vector of cereal diseases, including

\footnotetext{
* Correspondence: m.faheem@cabi.org; faheem.ahmad@comsats.edu.pk 'Department of Entomology, Faculty of Agricultural Science and Technology, Bahauddin Zakariya University, Multan 60800, Pakistan

${ }^{6}$ Department of Biosciences, COMSATS University Islamabad (CUI), Park Road, Tarlai Kalan, (ICT), Islamabad 45550, Pakistan

Full list of author information is available at the end of the article
}

yellow dwarf viruses (Chapin et al., 2001). The frequent use of insecticides poses severe threats to non-target species as well as to the environment. Hence, management strategies, using natural enemies of aphids (Cook et al., 2007), can keep the aphid population under control, and at the same time, it will decrease dependence upon chemical compounds.

Aphidophagous flies belonging to family Syrphidae are efficient predators of wheat aphids (Gilbert, 2005). Syrphid females lay their eggs in response to aphid density, and if their larvae hatch early in the build-up of aphid 
populations, they are often able to limit aphid outbreaks (Tenhumberg, 1995a, b and Smith et al., 2008).

The two important predatory species of syrphid flies, i.e., Ischiodon scutellaris (Fabricius) and Episyrphus balteatus (DeGeer), are aphidophagous and prey on many aphid species worldwide (Sadeghi and Gilbert, 2000). E. balteatus is commonly found in central Europe and South Asia (Tenhumberg, 1995b), whereas I. scutellaris is commonly distributed in Asia-Oceania countries as well as in Pakistan (Pape and Thompson, 2016). Both species are efficient predators of aphids in the natural agro-ecosystems (Steidle and van Loon, 2002) due to their high reproductive rates of females and voracious feeding potentials of their larvae (Ambrosino et al., 2007 and Almohamad et al., 2009).

The present study aimed to evaluate the prey potential of two syrphid species against the wheat aphid, Schizaphis graminum (Rondani), at different temperatures under laboratory conditions. The results may help in understanding the predators' capacity and survival under different temperatures.

\section{Materials and methods \\ Insect culturing}

More than 300 adult flies of I. scutellaris and E. balteatus were captured using sweep-nets from wheat fields at the research farms of Bahauddin Zakariya University, Multan, Punjab, Pakistan, to establish the stock cultures. After taxonomic identification and species confirmation, 10 couples of field-collected flies were released in oviposition cages $(70 \times 70 \times 100 \mathrm{~cm})$. The stock cultures were maintained at $25 \pm 2{ }^{\circ} \mathrm{C}, 65 \pm 5 \%$ R.H. and $16: 8$ h (L.D.) photoperiod. A cotton swab soaked in $50 \%$ honey solution was kept in each cage as fly diet (Wäckers et al., 2008). A total of three wheat plants infested with S. graminum were

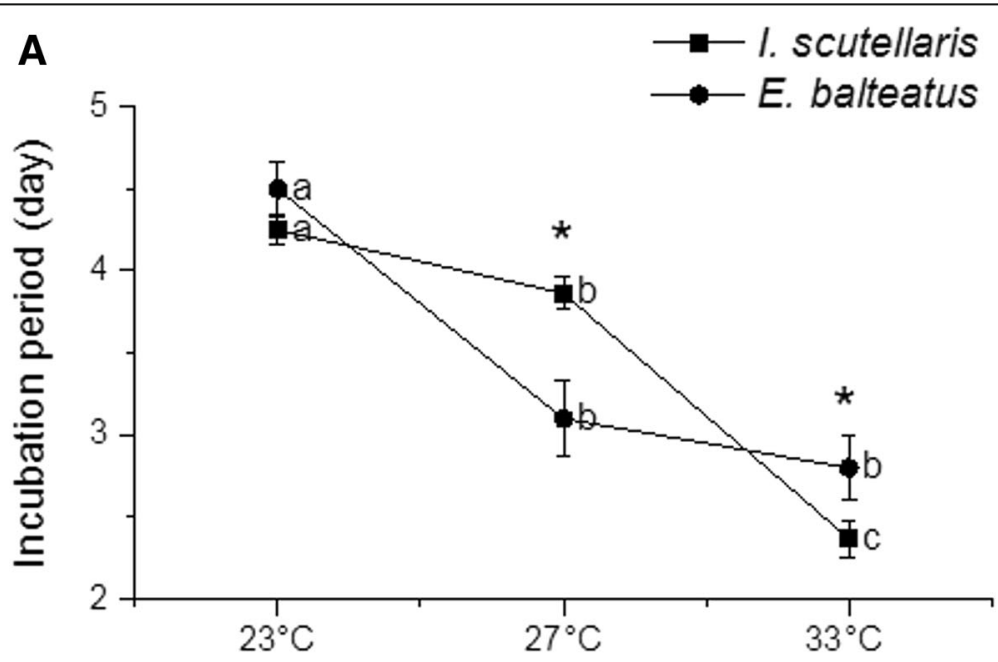

B

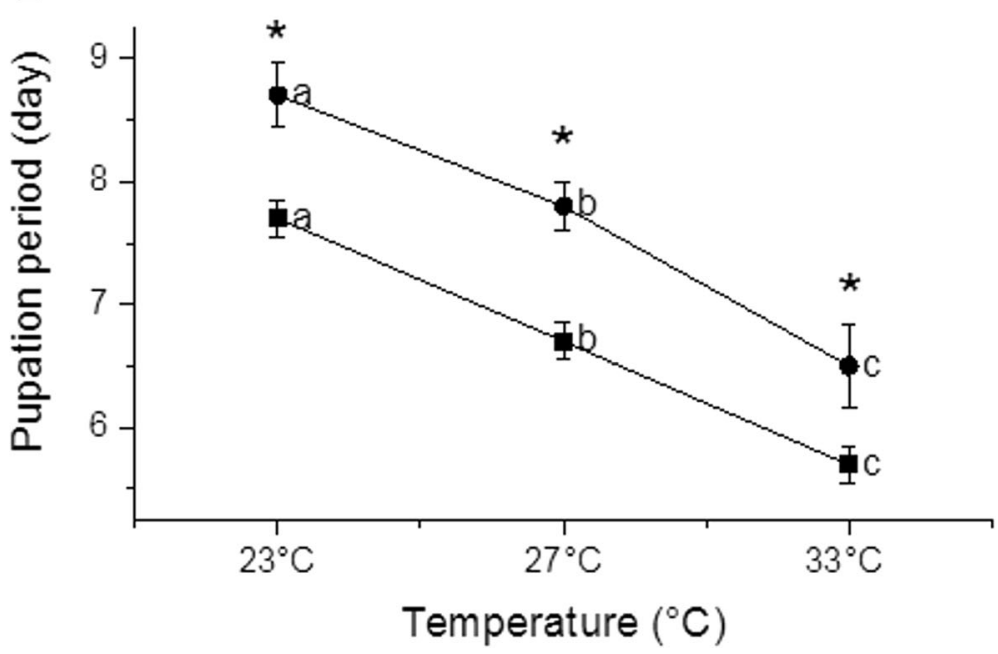

Fig. 1 Relative fitness of I. scutellaris and E. balteatus, under different temperature regimes, expressed in terms of egg incubation period (a) and pupation period (b). The data points presented are means \pm SEM. Different lowercase letters above each line demonstrate a significant difference among each data point, while an asterisk above a pair of data points presents a significant difference among two predator species $(P<0.05)$ 
offered inside the rearing cages consisting of polyvinyl chloride (PVC) poles and polyester fly mesh $(70 \times 70 \times$ $100 \mathrm{~cm}$ ). Fresh eggs of the syrphid flies laid on leaves were collected every $6 h$ by cutting their sections of leaves. Each individual egg, collected from the oviposition cages, was kept in a Petri dish $(9.6 \mathrm{~cm} \varnothing)$.

\section{Effect of temperatures on predator development and fitness}

To evaluate the fitness of the predatory species under different temperatures, the developmental time for immature stages of both predatory species was estimated at 23, 27, and $33^{\circ} \mathrm{C}$. Fertilized eggs and pupae $(n=10)$ of both the I. scutellaris and E. balteatus were obtained from the stock cultures and kept individually in Petri dishes $(9.6 \mathrm{~cm} \varnothing)$ at pre-set temperatures, $65 \pm 1 \%$ R.H. and 16:8 h (L.D.) photoperiod. This experiment was replicated three times, and data regarding egg incubation and pupation periods were recorded at an interval of $12 \mathrm{~h}$.

\section{Comparative development of predator species}

The data regarding egg incubation period, larval developmental time, pupation period, and adult (both male and female) lifespan were recorded at the interval of $12 \mathrm{~h}$. The bioassay was started by freshly laid fertilized eggs $(n=50)$ of each predatory species (kept individually in Petri dishes) until adult emergence. The Petri dishes were kept individually in netted rearing cages $(30 \times 30 \times 32 \mathrm{~cm})$. The cages were provided by potted wheat plants having $S$. graminum infestation to ensure the presence of food of hatching larvae. The aphid numbers in each cage were replenished to maintain food supply for larval development. Once the adult flies emerged, a cotton
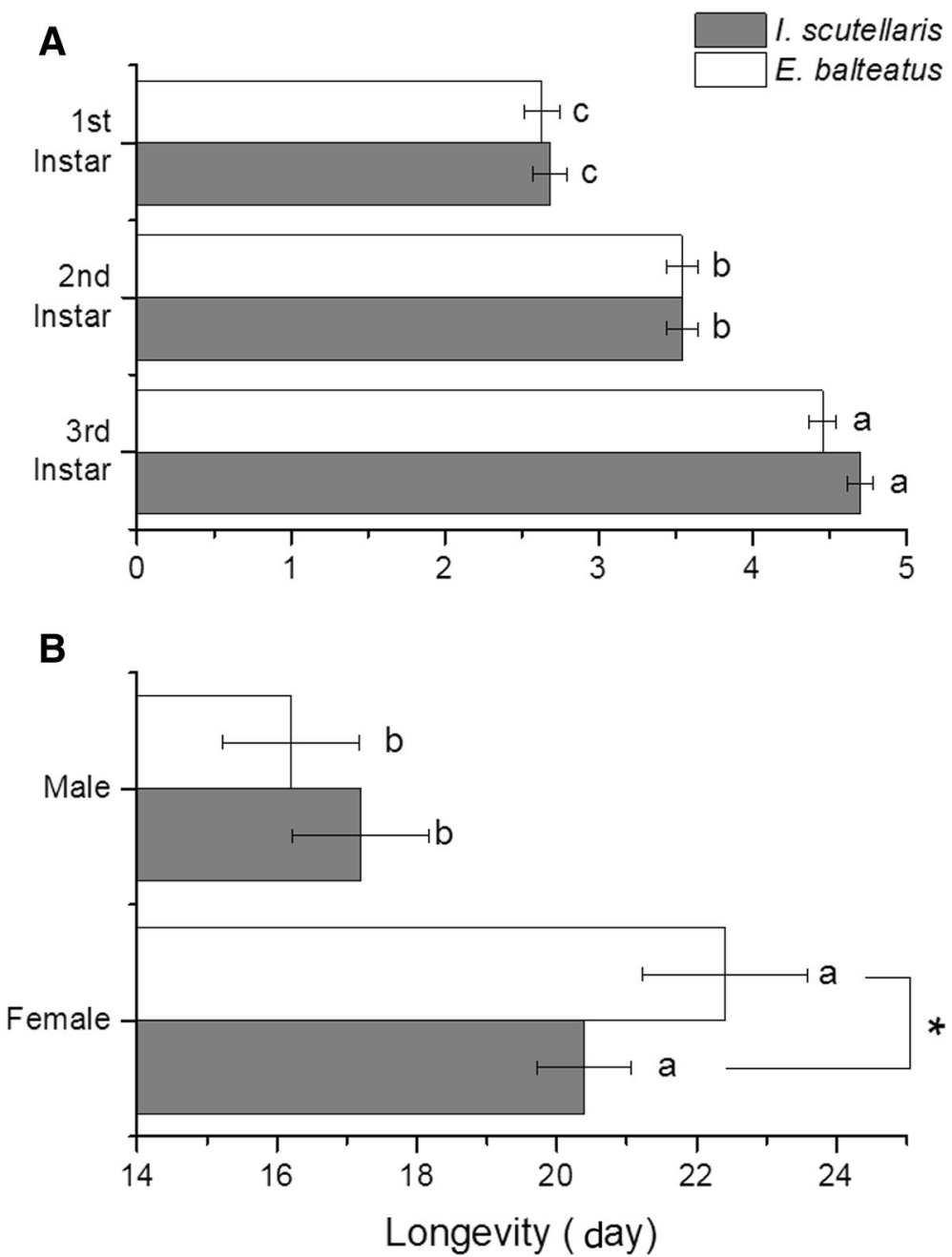

Fig. 2 Comparative fitness of larval instars (a) and adult flies (b) of I. scutellaris and E. balteatus, expressed in terms of developmental times of each stage. The bars are means \pm SEM, and the different lowercase letters above each bar demonstrate significant differences within the data, while an asterisk above a pair of the bars presents a significant difference between two predator species $(P<0.05)$ 
swab with $50 \%$ honey solution was provided as adult diet.

\section{Comparative predation rates}

For predation rate of $I$. scutellaris and E. balteatus, a total of 100 larvae (50 larvae/species) was evaluated. All the 50 larvae were daily provided by 20,50 , and 100 individuals of aphid during their 1st, 2nd, and 3rd instars, respectively. The data for predation was recorded every $24 \mathrm{~h}$. Petri dishes were cleaned daily by $70 \%$ ethanol. A control treatment was run in parallel, but without predators' larvae to account for the natural mortality of aphids $(n=100)$. The observed predation by syrphid larvae was corrected by subtracting the natural aphid mortality in the control treatment (Abbott, 1925).

\section{Data analysis}

The data of developmental periods and prey-consumption rates were subjected to statistical analysis, using two-way analysis of variance (ANOVA). Prior to analysis of variance, Levene test of homogenety was applied to confirm whether data meets the assumption of equal variances (Levene 1960). To compare the differences in developmental times between the predatory species, the data for each stage was compared, using student's $t$ test with $P=$ 0.05 . Where the differences were significant, the means were subjected to Bonferroni post hoc pairwise comparison tests at $P=0.05$ (Huck et al., 1974). All data were analyzed using SPSS version 17.0 software (SPSS, 2008).

\section{Results and discussions}

Effect of temperatures on predators' development and fitness

The egg incubation period was significantly affected by temperature in both $I$. scutellaris and $E$. balteatus species $\left(F_{2,89}=10.256 ; P<0.001\right)$. The incubation period decreased with increasing temperature (Fig. 1a). It did not differ significantly between the two species at the lowest temperature $\left(23^{\circ} \mathrm{C}\right)$, but E. balteatus developed faster at the intermediate temperature $\left(27^{\circ} \mathrm{C}\right)$, while $I$. scutellaris developed faster at the highest temperature $\left(33^{\circ} \mathrm{C}\right)$ (Fig. 1a). A maximum egg incubation period of $(4.25 \pm 0.09$ and $4.50 \pm 0.09)$ days was recorded at $23{ }^{\circ} \mathrm{C}$ for $I$. scutellaris and E. balteatus, respectively, while the minimum periods were $(2.37 \pm 0.11$ and $2.80 \pm$ 0.11 ) days, at $33^{\circ} \mathrm{C}$. Similar trend in the pupation periods for both species were observed, where I. scutellaris development was significantly faster than $E$. balteatus under different temperature regimes $\left(F_{1,54}=28.562 ; P<0.001\right)$ (Fig. $\left.1 \mathrm{~b}\right)$. Also, different temperatures alter the pupation periods of both species significantly $\left(F_{2,54}=45.068 ; P<0.001\right)$. The shortest pupation period ( $5.70 \pm 0.15$ days) was observed for I. scutellaris at $33^{\circ} \mathrm{C}$, while the longest $(8.70 \pm 0.26$ days $)$ was for E. balteatus at $23^{\circ} \mathrm{C}$ (Fig. 1b).

The population density of the predator is correlated with prey populations (Haenke et al., 2009; Singh and Singh, 2013) as well as to the abiotic conditions including temperature, relative humidity, rainfall, and wind speed in the ecosystem (Kalita and Singh, 2012). The developmental times of both species were greatly reduced at $33^{\circ} \mathrm{C}$. The

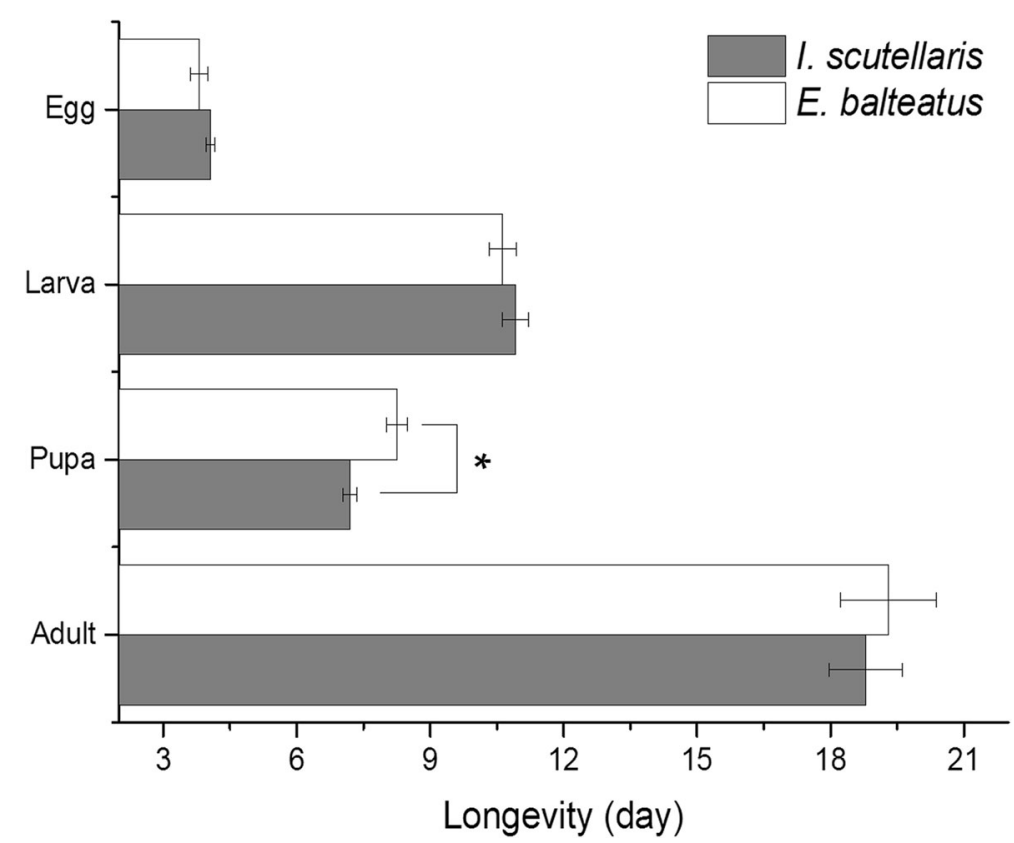

Fig. 3 Comparative developmental times of different life stages of I. scutellaris and E. balteatus. The bars are means \pm SEM, and an asterisk above a pair of the bars presents a significant difference between two predator species $(P<0.05)$ 
predator released at a higher or a lower temperature than the average may lead to the quick or slow development, respectively, without synchronizing with aphid population build-up. Hence, releasing the natural enemies at an optimum time is a requisite for biocontrol success in the field. Our results support this hypothesis where the intermediate temperature $\left(27^{\circ} \mathrm{C}\right)$ was the optimum for optimum development of biological control to maximize their chances to sync with aphid population upon release. A considerable number of earlier studies have reported the dependence of syrphid predator success on temperatures (Ankersmit et al., 1986; Tenhumberg, 1995b; Bianchi et al., 2006).

\section{Comparative development and predation rates}

Concerning larval and adult durations, insignificant difference between $I$. scutellaris and $E$. balteatus was recorded $\left(F_{1,146}=1.433 ; P=0.23\right)$ and $\left(F_{1,36}=0.266 ; P=0.61\right)$, respectively. But the females of $E$. balteatus lived significantly

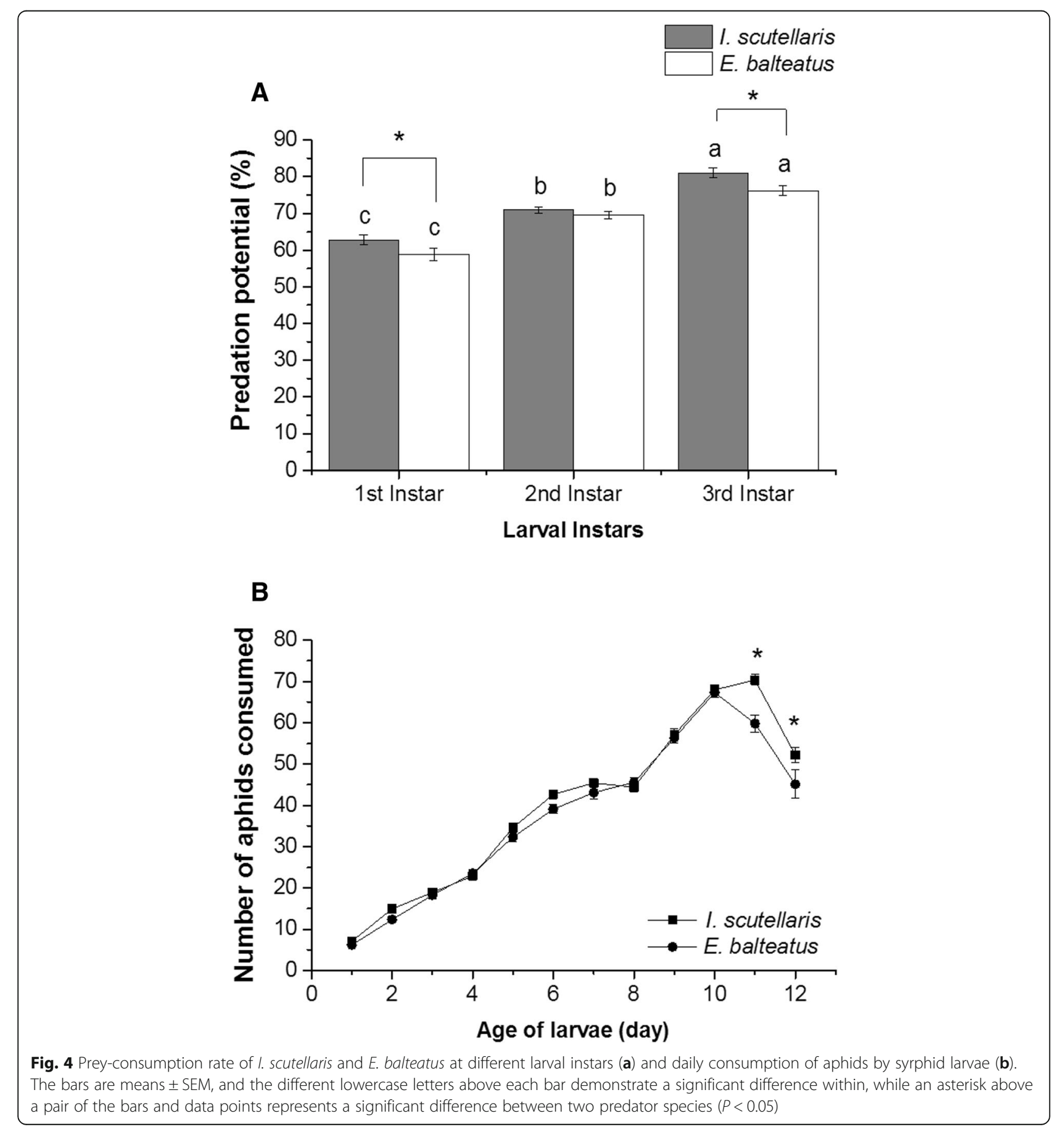


longer than that of $I$. scutellaris $\left(F_{1,146}=1.433 ; P=0.23\right)$. However, duration of different larval instars and adult lifespan of male and female flies of each species differed significantly $\left(F_{2,146}=189.399 ; P<0.001\right)$ and $\left(F_{2}, 36=23.527\right.$; $P<0.001$ ), respectively (Fig. 2). The 3rd instar larvae of both $I$. scutellaris and E. balteatus lasted a maximum time ( $4.70 \pm 0.08$ and $4.45 \pm 0.09$ days, respectively), followed by the 2nd instar $(3.54 \pm 0.10$ and $3.53 \pm 0.18$ days, respectively) and then 1st instar larvae $(2.67 \pm 0.11$ and $2.63 \pm 0.11$ days, respectively) (Fig. 2a). In general, the female flies lived $30 \%$ longer than that of males (Fig. 2b).

The developmental periods expressed as egg, larval, and adult durations exhibited insignificant differences between $I$. scutellaris and $E$. balteatus $(t=1.912 ; d . f .=32$; $P=0.07), \quad(t=1.078 ; d . f .=36 ; P=0.29)$, and $(t=0.458$; d.f. $=18 ; P=0.65$ ) (Fig. 3 ). Only the pupation period was

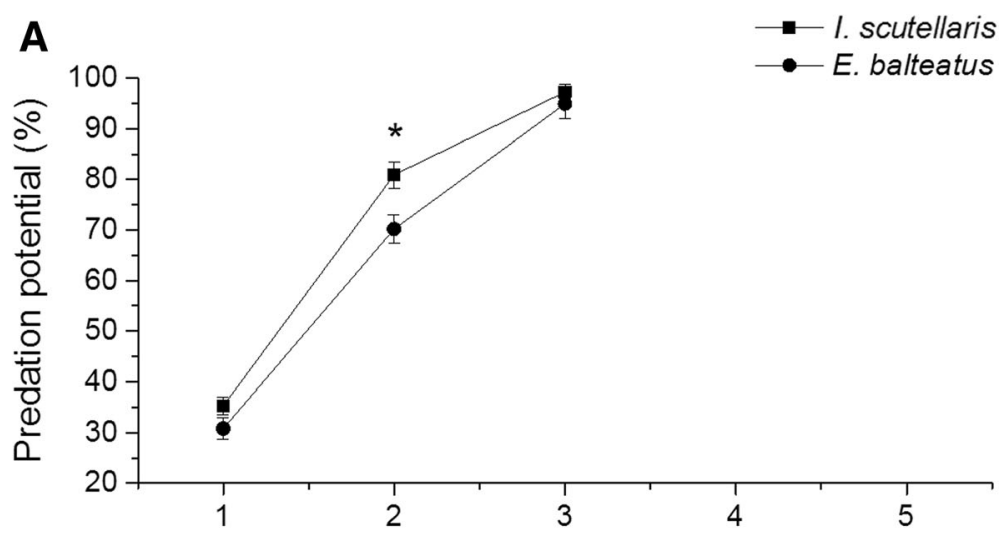

B

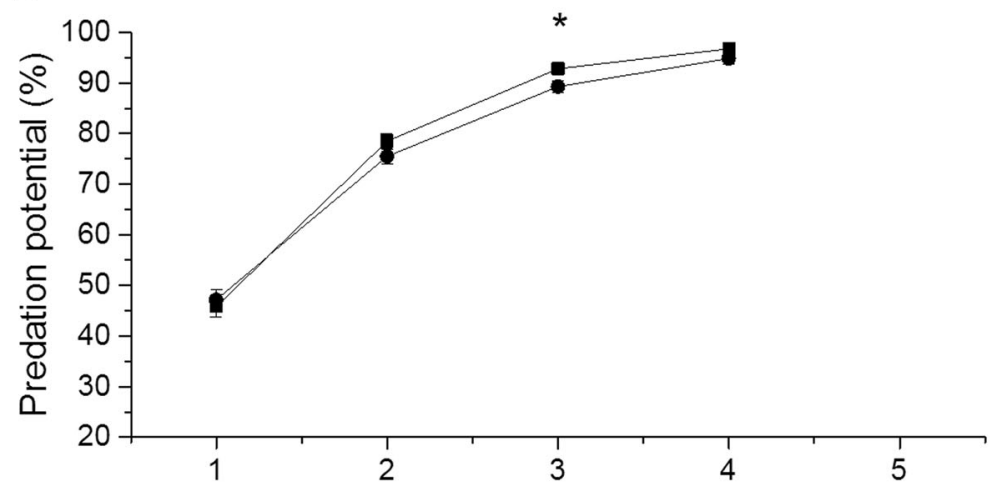

C

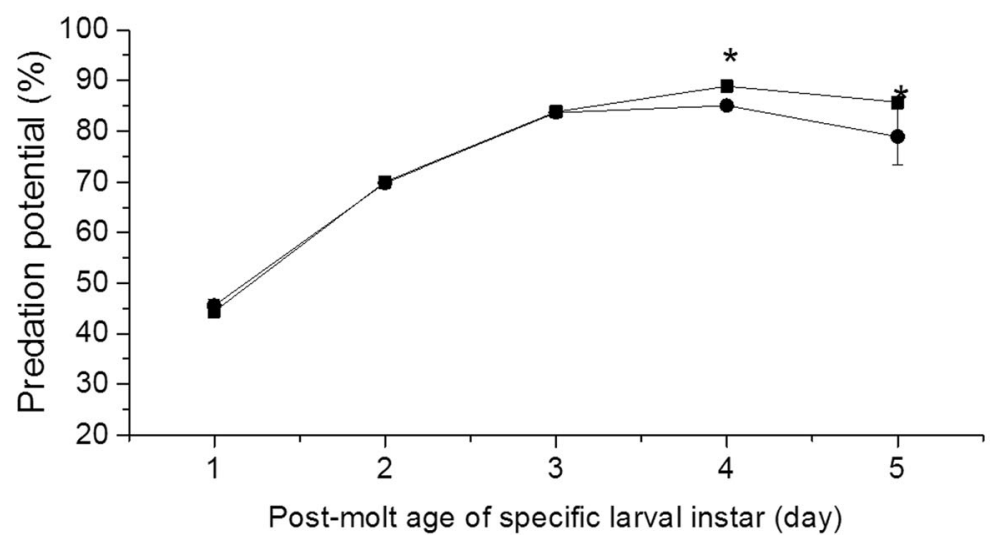

Fig. 5 Daily prey-consumption rate of 1 st (a), 2nd (b), and $3 \mathrm{rd}(\mathbf{c})$ instar larvae of I. scutellaris and E. balteatus. The data points presented are means \pm SEM. The data points where the SEM overlaps are not statistically different from one another $(P<0.05)$ 
found significantly different between both predatory species $(t=5.166 ; d . f .=18 ; P<0.001)$, where the pupae of $I$. scutellaris completed its stage earlier than that of E. balteatus (Fig. 3).

The predation rates expressed in terms of percentage of prey consumption was significantly different between both predatory species and their larval instars $\left(F_{1,146}=9.669 ; P<0.001\right.$ and $F_{1,146}=88.624 ; P<0.001$, respectively) (Fig. 4a). The 1st and 3rd instar larvae of $I$. scutellaris had significantly higher predatory potentials $(62.83 \pm 1.32$ and $81.05 \pm 1.36 \%$, respectively) than same stage larvae of $E$. balteatus (58.86 \pm 1.66 and $76.12 \pm$ $1.35 \%$, respectively) (Fig. 4), while the 2nd instar larvae of both species did not differ significantly from each other in terms of their predatory potentials $(70.85 \pm 0.85$ and 69.51 $\pm 0.10 \%$, respectively) (Fig. 4a). The highest predation rates were clearly observed in the $3 r d$ instar of both predator species (Fig. 4a).

The data regarding total predation by larvae (cumulative of all instars) revealed that I. scutellaris larvae consumed significantly higher numbers of aphids as compared to that of $E$. balteatus (i.e., $438.16 \pm 10.76$ and $398.37 \pm 9.45$ aphids $)\left(F_{1,36}=7.715 ; P=0.009\right)$. The larvae of both species had similar voracity until 10 days after hatching (Fig. 4b), while the older larvae (3rd instar) of I. scutellaris consumed higher numbers of aphids per day as compared with E. balteatus (Fig. 4b). In general, the predation rates on daily basis increased with each successive instar but near the time of molt, this predation declined (Fig. 5a-c). Obtained results demonstrated that the predation rate of both species increased with each successive instar, and they had consumed a total of 30-33 aphids during 1st instar, 110-120 aphids during 2nd instar, and 253-278 aphids during their 3rd instar. The average daily aphid intake was recorded to be increased up to $90 \%$ on the 11th day of larval stage (i.e., 4th day since the 2nd molt) (Fig. 5c).

The results have strongly suggested the voracious nature of 3rd instar larvae, and the release of 3rd instar larvae can be a highly efficient approach. The findings are in accordance with the earlier reports suggesting the highest prey-consumption rates of syrphid flies in their 3rd instars (Völkl et al., 2007 and Singh and Singh, 2013). Since both predatory species were found equally efficient against aphids, the use of their mixed cultures for aphid biological control in wheat needs to be studied.

The success of a biological control agents in the field depends upon the reproductive success of the females (Lundgren et al., 2008) and the developmental time of females and their physiological fitness that leads towards greater ovipositional potential (Arnqvist and Nilsson, 2000). In addition, the females of both $I$. scutellaris and E. balteatus had significantly higher lifespan compared to the males, while the females of $E$. balteatus had significantly longer lifespan than I. scutellaris, suggesting the competitive advantage to the former species.

\section{Conclusion}

Being eco-friendly approach, using syrphid flies as the biological control agents against wheat aphid may provide a complementary management method to minimize chemical control. Further research can be helpful in assessing competitive synergies of using both predatory species together in the field, as well as, refining the methods for field release and augmentation.

\section{Acknowledgements}

We were very grateful to Rana Muhammad Shafique and Abdul Rehman (CABI, Pakistan) for his critical review and elucidating discussions which improved the manuscript. We also thank Dr. Waqar Jaleel for his valuable assistance in lab work

Funding

Not applicable.

Availability of data and materials

The datasets used and/or analyzed during the current study are available from the corresponding author on reasonable request.

\section{Authors' contributions}

All authors have contributed significantly as expressed below. MF conceived the idea, planned and executed the trials, collected the data, and wrote the earlier drafts of the manuscript. SS conceived the idea and planned the experiments. AS contributed to the literature review and early manuscript preparation. MR conceived the idea and provided guidance in planning the experiments. FA helped in data handling, data analysis and data

presentation, and final manuscript write-up. All authors read and approved the final manuscript.

Ethics approval and consent to participate

Not applicable - the study was conducted on insect species that are abundant in ecosystem and does not required ethical approval.

Consent for publication

Not applicable

Competing interests

The authors declare that they have no competing interests.

\section{Publisher's Note}

Springer Nature remains neutral with regard to jurisdictional claims in published maps and institutional affiliations.

\section{Author details}

${ }^{1}$ Department of Entomology, Faculty of Agricultural Science and Technology, Bahauddin Zakariya University, Multan 60800, Pakistan. ${ }^{2}$ CABI South East Asia, Building A19, Glasshouse Complex, MARDI, Serdang, Selangor 43300,

Malaysia. ${ }^{3}$ Department of Entomology, Muhammad Nawaz Shareef University of Agriculture Multan, Old Shujaabad Road, Multan 60000, Pakistan. ${ }^{4}$ Department of Entomology, University College of Agriculture and Environmental Sciences, The Islamia University of Bahawalpur, Bahawalpur 63100, Pakistan. ${ }^{5}$ Department of Entomology, Faculty of Agricultural Science and Technology, Bahauddin Zakariya University, Multan 60800, Pakistan.

${ }^{6}$ Department of Biosciences, COMSATS University Islamabad (CUI), Park Road, Tarlai Kalan, (ICT), Islamabad 45550, Pakistan. 
Received: 15 August 2018 Accepted: 3 January 2019

Published online: 15 January 2019

\section{References}

Abbott WS (1925) A method of computing the effectiveness of an insecticide. J Econ Entomol 18:265-267

Almohamad R, Verheggen FJ, Haubruge É (2009) Focus on searching and oviposition behavior of aphidophagous hoverflies (Diptera: Syrphidae): a review. Biotechnol Agron Soc Environ 13:467-481

Ambrosino M, Jepson P, Luna J (2007) Hoverfly oviposition response to aphids in broccoli fields. Entomol Exp Appl 122:99-107

Ankersmit GW, Dijkman H, Keuning NJ, Mertens H, Sins A, Tacoma HM (1986) Episyrphus balteatus as a predator of the aphid Sitobion avenae on winter wheat. Entomol Exp Appl 42:271-277. https://doi.org/10.1111/j.1570-7458. 1986.tb01032.x

Arnqvist G, Nilsson T (2000) The evolution of polyandry: multiple mating and female fitness in insects. Anim Behav 60:145-164

Belay T, Araya A (2015) Grain and biomass yield reduction due to Russian wheat aphid on bread wheat in northern Ethiopia. Afr Crop Sci J 23:197-202

Bianchi FJ, Booij C, Tscharntke T (2006) Sustainable pest regulation in agricultural landscapes: a review on landscape composition, biodiversity and natural pest control. Proc Royal Soc London B: Biol Sci 273:1715-1727

Chapin JW, Thomas JS, Gray SM, Smith DM, Halbert SE (2001) Seasonal abundance of aphids (Homoptera: Aphididae) in wheat and their role as barley yellow dwarf virus vectors in the South Carolina coastal plain. J Econ Entomol 94:410-421

Cook SM, Khan ZR, Pickett JA (2007) The use of push-pull strategies in integrated pest management. Annu Rev Entomol 52:375-400

Gilbert F (2005) Syrphid aphidophagous predators in a food-web context. Eur J Entomol 102:325-333

Haenke S, Scheid B, Schaefer M, Tscharntke T, Thies C (2009) Increasing syrphid fly diversity and density in sown flower strips within simple vs. complex landscapes. J Appl Ecol 46:1106-1114

Huck SW, Cormier WH, Bounds WG (1974) Reading statistics and research. Harper \& Row New York

Kalita J, Singh T (2012) Biological control potential of an aphidophagous syrphid, Episyrphus balteatus, De-Geer (Diptera: Syrphidae) on mustard aphid, Lipaphis erysimi (Kalt.)(Homoptera: Aphididae) on cabbage ecosystem in Manipur. J Exp Sci 2:13-16

Levene H (1960) Robust tests for the equality of variance. In: Olkin I (ed) Contributions to probability and statistics. Stanford University Press, Paolo Alto, pp 278-292

Lundgren JG, Fergen JK, Riedell WE (2008) The influence of plant anatomy on oviposition and reproductive success of the omnivorous bug Orius insidiosus. Anim Behav 75:1495-1502

Pape T, Thompson C (2016) Sherborn's influence on Systema dipterorum. ZooKeys 550:135-152. https://doi.org/10.3897/zookeys.550.9447

Sadeghi H, Gilbert F (2000) Aphid suitability and its relationship to oviposition preference in predatory hoverflies. J Anim Ecol 69:771-784. https://doi.org/ 10.1046/j.1365-2656.2000.00433.x

Singh K, Singh NN (2013) Preying capacity of different established predators of the aphid Lipaphis erysimi (Kalt.) infesting rapeseed-mustard crop in laboratory conditions. Plant Prot Sci 49:84-88

Smith HA, Chaney WE, Bensen TA (2008) Role of syrphid larvae and other predators in suppressing aphid infestations in organic lettuce on California's central coast. J Econ Entomol 101:1526-1532. https://doi.org/10.1093/jee/101.5.1526

SPSS (2008) SPSS Statistics for Windows, Version 17.0. Chicago

Steidle JL, van Loon JJ (2002) Chemoecology of parasitoid and predator oviposition behaviour. In: Hilker M, Meiners T (eds) Chemoecology of insect eggs and egg deposition. Balckwell Publishing, Berlin, pp 291-317

Tenhumberg B (1995a) Estimating predatory efficiency of Episyrphus balteatus (Diptera: Syrphidae) in cereal fields. Environ Entomol 24:687-691. https://doi. org/10.1093/ee/24.3.687

Tenhumberg B (1995b) Syrphids as natural enemies of cereal aphids in Germany: aspects of their biology and efficacy in different years and regions. Agric Ecosyst Environ 52:39-43. https://doi.org/10.1016/0167-8809(94)09007-t

VölkI W, Mackauer M, Pell JK, Brodeur J (2007) Predators, parasitoids and pathogens. In: Aphids as crop pests. CAB international, Oxford, pp 187-233

Wäckers FL, Van Rijn PC, Heimpel GE (2008) Honeydew as a food source for natural enemies: making the best of a bad meal? Biol Control 45:176-184

\section{Submit your manuscript to a SpringerOpen ${ }^{\circ}$ journal and benefit from:}

- Convenient online submission

- Rigorous peer review

- Open access: articles freely available online

High visibility within the field

- Retaining the copyright to your article

Submit your next manuscript at $\boldsymbol{\nabla}$ springeropen.com 